\title{
Informacje/Information
}

DOI : $10.14746 / \mathrm{pp} .2015 .20 .3 .17$

\section{Zapisy ustawy o mniejszościach narodowych $i$ etnicznych oraz o jezyku regionalnym a oczekiwania Ślqzaków - dyskusja panelowa zapis z wprowadzeniem}

Termin: 7 maja 2015.

Organizator: Wydział Nauk Politycznych i Dziennikarstwa Uniwersytetu im. Adama Mickiewicza w Poznaniu

Patronat: Komisja Mniejszości Narodowych i Etnicznych (Sejm RP), Wielkopolski Urząd Wojewódzki

\section{Uwagi wprowadzające}

U podstaw zjawisk separatystycznych z przełomu XIX i XX wieku na Górnym Śląsku leży historia tego regionu, który do połowy XIX wieku charakteryzowała peryferyjność w stosunku do głównych procesów modernistycznych, którym podlegały narody zabiegające o przychylność (głosy) Górnoślązaków. Występowały więc wielowiekowe związki ludności tego regionu początkowo z Królestwem Polskim, Królestwem Czeskim, następnie z Habsburgami, a od połowy XVIII wieku z Królestwem Pruskim oraz okres rozwoju kapitalizmu, kiedy to w efekcie napływu niemieckich przedsiębiorców, kadry administracyjnej i masowych przemieszczeń się ludności śląskiej z terenów wiejskich do rozwijających się miast górnośląskich i doświadczanie najczęściej awansu cywilizacyjnego i znajdowanie się pod silnym wpływem niemieckiego etosu kulturowego. Wpływało to na zmianę przede wszystkim identyfikacji kulturowej Górnoślązaków, gdyż do połowy XIX wieku trudno było mówić o świadomości narodowej ludności wiejskiej w Europie w ogóle, a we wschodniej części kontynentu, zorganizowanego w cztery wielokulturowe byty polityczne w szczególe. Z jednej strony występujące wcześniej zjawisko symbiozy różnych rzeczywistości kulturowych, z którym mieliśmy do czynienia na Górnym Śląsku z umocnieniem poczucia swojej odrębności w konfrontacji z „obcymi”. Z drugiej strony, konfrontacja ta w przypadku przybyszów z terenów zacofanych kulturowo i cywilizacyjnie (Galicja, Królestwo Kongresowe) pozwalała wykształcić u Górnoślązaków poczucie wyższości w stosunku ludności, która choć posługiwała się takim samym (podobnym) językiem, to kulturowo od nich się różniła. To uświadamianie sobie odmienności początkowo rodziło dystans, by wraz ze wzrostem liczby napływających, co zagrażało miejscom i warunkom pracy, przerodzić się we wrogość ujawniającą się przy różnych okazjach. Z całą mocą należy podkreślić, że wielowiekowe oderwanie tej ludności, niewątpliwie słowiańskiego pochodzenia, od procesów modernizacyjnych, którym podlegał polski etos kulturowy, zwłaszcza, że od końca XVIII wieku również on musiał zabiegać o przetrwanie, wpłynęło na postrzeganie polskiej oferty kulturowej jako relatywnie najbardziej odległej od dotychczasowych doświadczeń Górnoślązaków. Odległej w stosunku głównie do oferty niemieckiej i w nieco mniejszym stopniu w stosunku do oferty czeskiej. O wyniku rywalizacji między ofertą polską i niemiecką miała, i jak się okazuje nadal ma, zadecydować ludność labilna narodowościowo. W efekcie procesy, które ujawniły się na przełomie XIX i XX wieku, rozwijały się przez cały okres dwudziestolecia międzywojennego, wystappiły ponownie na przełomie XX i XXI wieku. Mowa tu o pojawieniu się stanu pośredniego między opcją polską i niemiecką na Górnym Śląsku, a mianowicie opcji śląskiej jako bytu samego w sobie, której najbardziej spektakularnym przejawem jest artykułowanie stwierdzenia ,to my jesteśmy u siebie”. 


\section{Uczestnicy dyskusji ${ }^{1}$}

Dietmar Brehmer. Socjolog i pedagog, ukończył studia w Akademii Wychowania Fizycznego w Warszawie, był członkiem polskiej kadry narodowej w lekkiej atletyce $(100 \mathrm{~m}-10,50 \mathrm{~s})$ i w szermierce (szabla, brązowy medal mistrzostw Polski). W wyborach w 1989 i 1991 ubiegał się o mandat senatorski w województwie katowickim (za drugim razem zebrał 130 tys. głosów, co dało mu 10 miejsce wśród 22 kandydatów). Na początku lat 90. założył Niemiecką Wspólnotę Roboczą „Pojednanie i Przyszłość”, która ubiegała się o mandaty w wyborach samorządowych i parlamentarnych. W 2001 z jej ramienia startował w wyborach do Sejmu. W 2004 znalazł się wśród założycieli Jedności Górnośląskiej, skupiającej m.in. Związek Górnośląski i Ruch Autonomii Śląska. Jest założycielem i prezesem Górnośląskiego Towarzystwa Charytatywnego, a także wydawcą czasopisma „Hoffnung”. Autor i realizator Górnośląskiego Magazynu Mniejszości Niemieckiej „Pojednanie i Przyszłość” w Polskim Radiu Katowice (od 1991).

Niemiecka Wspólnota „Pojednanie i Przyszlość”. Statutowym celem powołanej do życia 1 lutego 1991 roku Niemieckiej Wspólnoty „Pojednanie i Przyszłość”, jest pełnienie łącznika pomiędzy mniejszością pochodzenia niemieckiego a społeczeństwem polskim. Cele te realizuje m.in. poprzez pielęgnowanie języka kultury i historii niemieckiej, w drodze organizowania szkolnictwa w języku niemieckim, kursów nauczania języka niemieckiego. Wspólnota działa na rzecz odrodzenia kultury niemieckiej i języka niemieckiego na Górnym Śląsku.

Wspólnota jest współzałożycielem Polsko-Niemieckiego Liceum Ogólnokształcącego w Zabrzu im. Królowej Jadwigi, posiada swój własny klub sportowy - sekcję piłki nożnej (ćwierćfinał Mistrzostw Europy Mniejszości Narodowych w Szwajcarii w 2008 r.). Organizuje opiekę nad osobami bezdomnymi, z własnym Ośrodkiem Socjalnym oraz dysponuje Domem dla Bezdomnych i Ogrzewalnią dla Bezdomnych. Wydaje codziennie ciepłe posiłki dla bezdomnych ( 150 tys. obiadów rocznie). Stale odbywają się kursy języka niemieckiego, niemiecki studencki teatrzyk, a także szereg imprez kulturalnych.

Piotr (Pejter) Długosz. Prowadzi własną firmę, zajmującą się m.in. tłumaczeniami, handlem energią elektryczna, gazem i certyfikatami $\mathrm{CO}_{2}$ oraz sprzedażą śląskich pamiątek. Tematyka śląska pochłonęła go podczas studiów, które skończył obroną pracy magisterskiej pod tytułem: Dażenia autonomiczne na Górnym Ślqsku w latach 1918-1922. Członek Towarzystwa Społeczno-Kulturalnego Niemców (TSKN) na Śląsku Opolskim do momentu, w którym zaangażował się w współtworzenie opolskich struktur Ruchu Autonomii Śląska. W 2004 r. założył stowarzyszenie Młodzież Górnośląska, którego był także pierwszym przewodniczącym. Był również jednym ze współzałożycieli zarejestrowanego w grudniu 2011 roku przez Sąd Rejonowy w Opolu Stowarzyszenia Osób Narodowości Śląskiej (SONŚ), którego pracami do dnia dzisiejszego kieruje.

Stowarzyszenie Osób Narodowości Śląskiej. Ze Statutu SONŚ: „Celem Stowarzyszenia jest: pielęgnowanie śląskiej tożsamości, odrodzenie kultury śląskiej, propagowanie wiedzy o Śląsku, kształtowanie i rozwijanie wśród wszystkich mieszkańców Śląska aktywnej postawy obywatelskiej, współuczestniczenie we współczesnej integracji wszystkich zamieszkujących Sląsk grup ludności, podtrzymywanie kontaktów kulturowych między Ślązakami bez względu na miejsce zamieszkania oraz pomoc osobom chętnym do powrotów z emigracji zarobkowej, promocja i kształtowanie pozytywnego wizerunku Śląska i Ślązaków, dbanie o zachowanie materialnego i duchowego dziedzictwa Śląska”. Liderzy SONŚ deklarują apolityczność, gdy stwierdzają, iż nie

\footnotetext{
${ }^{1}$ Informacje o uczestnikach dyskusji i organizacjach, które reprezentują pochodzą z ich stron internetowych.
} 
będą rejestrować komitetów wyborczych. Założyciele w statucie zapisali punkt, że nie mogą powoływać komitetu wyborczego w wyborach parlamentarnych. Komitet założycielski stanął na stanowisku, że marka SONŚ nie powinna być wykorzystywana do jakichkolwiek celów zdefiniowanych politycznie w tym samorządowych.

Dr Jerzy Gorzelik. Ukończył historię sztuki na Uniwersytecie Jagiellońskim. W 1999 uzyskał stopień doktora nauki o sztukach pięknych na Uniwersytecie Wrocławskim na podstawie rozprawy Etapy przemian sztuki barokowej w opactwie cysterskim w Rudach Wielkich kolo Raciborza. Został pracownikiem naukowym Wydziału Nauk Społecznych Uniwersytetu Sląskiego na etacie adiunkta w Zakładzie Historii Sztuki. Od 1996 r. krótko działał w Lidze Republikańskiej. W drugiej połowie lat 90. został jednym z liderów Związku Ludności Narodowości Śląskiej (ZLNŚ). Z tamtego okresu opinia publiczna poznała go jako autora stwierdzenia: „nie czuję się Polakiem tylko Górnoślązakiem, a tym samym nie czuję się zobowiązany do lojalności wobec Polski”. Przez cały czas aktywnie działa na rzecz uznania narodowości śląskiej za odrębną, względem polskiej. Od samego początku aktywnie angażował się w działalność Ruchu Autonomii Śląska (RAŚ). W organizacji tej pełnił funkcję rzecznika prasowego, kierował katowickim kołem ruchu. W $2003 \mathrm{r}$. został przewodniczącym RAŚ. W okresie jego kierownictwa organizacja ta zrezygnowała z radykalnych haseł, koncentrując się na upowszechnianiu śląskiej kultury i tożsamości.

Ruch Autonomii Śląska. Stowarzyszenie utworzone w styczniu 1990 r. na Górnym Śląsku. Od 27 czerwca 2001 r. stowarzyszenie z siedzibą w Katowicach. Głównym celem organizacji jest utworzenie autonomicznego regionu w historycznych granicach Górnego Śląska. Najbardziej widocznym sukcesem RAŚ była agitacja przed spisem powszechnym w 2002 roku prowadzona pod hasłem „Masz prawo zadeklarować narodowość śląską”. Aktualnie działacze Ruchu są zaangażowani w promowanie idei powołania Sląskiej Partii Regionalnej, której celem ma być doprowadzenie do pełnej samorządności regionu.

Piotr Spyra. Absolwent Wydziału Nauk Społecznych Uniwersytetu Śląskiego. Po studiach pracował jako nauczyciel, a następnie urzędnik w Urzędzie Kontroli Skarbowej. W 2006 r. objął stanowisko zastępcy prezesa zarządu Międzynarodowej Giełdy Towarowej. Jest jednym z założycieli powstałego w 1997 r. Ruchu Obywatelskiego „Polski Śląsk” (RO,PS”), którym kieruje do dnia dzisiejszego. W wyborach samorządowych w 2010 r. z listy PO uzyskał reelekcję do sejmiku województwa śląskiego, otrzymując ok. 13 tys. głosów. W dniu 17 lutego 2011 r. powołany został na stanowisko drugiego wicewojewody śląskiego.

Ruch Obywatelski „Polski Śląsk”. Organizacja nawiązująca jednoznacznie do tradycji polskości Górnego Śląska. Ruch deklaruje poparcie dla wszelkich inicjatyw dążących do rzeczywistej integracji mieszkańców Górnego Śląska, opowiada się za silnym samorządnym Województwem Górnośląskim w ramach unitarnego Państwa Polskiego. Ruch Obywatelski „Polski Śląsk” wspiera zdrowy regionalizm śląski, zakorzeniony w polskości i kulturze chrześcijańskiej.

Dr Waldemar Szendera. Doktor biologii. Ukończył Ogrodniczą Zasadniczą Szkołę Zawodową, potem Państwowe Technikum Ogrodnicze w Bielsku-Białej. W 1988 r. zrobił dyplom magisterski na Uniwersytecie Śląskim. W latach 90. odbył wyjazdy studyjne na Uniwersytecie Filipa w Marburgu w Niemczech i w Wegeningen w Holandii. Jest twórcą i kierownikiem Śląskiego Ogrodu Botanicznego w Mikołowie Mokrem. Jednocześnie wspólnie z ojcem prowadzi w Suszcu gospodarstwo szkółkarskie drzew, krzewów i bylin ozdobnych. Zainteresowania: narciarstwo, systematycznie gra w piłkę halową, lubi wędrówki w celu poznawania świata, w rodzinnym gospodarstwie posiada prywatne muzeum etnograficzne. Od marca 2014 roku członek Zarządu Związku Górnośląskiego. 
Związek Górnośląski. U podstaw jego działalności leży zamiar obrony wartości kulturowych i cywilizacyjnych Górnego Śląska, powstałych na gruncie chrześcijańskim jak również dążność do integracji społeczności regionu wokół jego wartości dawnych i nowych oraz do harmonijnego rozwoju zamieszkałej tu ludności, zapewniającego dobro każdej osoby.

Związek uznaje za swoje dziedzictwo wartości przekazywane przez:

a) wielkich Ślązaków - budzicieli świadomości moralnej i narodowej duchownych obu wyznań, społeczników, intelektualistów i artystów;

b) zakony górnośląskie, m.in. cystersów, bożogrobców, franciszkanów, dominikanów, jezuitów oraz diakonackie wspólnoty ewangelickie;

c) organizacje górnośląskie takie jak Górnośląskie towarzystwo Akademickie sprzed I wojny światowej, Macierz Szkolną, Alojzjanów, Sokoła, Eleusis, Silesia Superior, Towarzystwo Przyjaciół Nauk na Śląsku, Związek Polaków w Niemczech, Związek Polaków w Czechosłowacji, Związek Powstańców Śląskich i Obrońców Górnego Śląska we wrześniu 1939 r., żołnierzy Armii Krajowej na Śląsku i Śląskich Szarych Szeregów.

\section{Przebieg dyskusji}

Prowadzący, dr Cezary Trosiak (Wydział Nauk Politycznych i Dziennikarstwa UAM)

Szanowni Państwo jest mi niezmiernie miło przywitać uczestników dyskusji na temat aspiracji części mieszkańców Górnego Śląska do tego, aby byli oni uznani za odrębną grupę etniczną czy wręcz narodową. Z uwagi na fakt, że urodziłem się w opolskiej części Górnego Śląska, z tematem tym jestem konfrontowany niemal od samego początku swojego świadomego doświadczania rzeczywistości społecznej. Kiedy w roku 1979 przyjechałem do Poznania na studia socjologiczne, zarówno dla moich koleżanek i kolegów, jak i dla wykładowców, opowieści o zjawiskach społecznych charakterystycznych dla regionu, z którego przyjechałem do Wielkopolski, brzmiały jak opowieści z innego kraju. Jestem przekonany, że podobne wrażenie odniosą obecni na tej sali studenci, którzy zapewne po raz pierwszy zostaną skonfrontowani z treścią i temperaturą społeczną dyskusji/sporu jaki toczy się na obecnie na Górnym Śląsku. Z uwagi na czas, jaki zaplanowaliśmy dla tej dyskusji od razu przejdę do pytań, które postawiliśmy przed naszymi gośćmi. Pytanie pierwsze, do którego proszę byście panowie się ustosunkowali, to pytanie o to jakie są argumenty na rzecz uznania, bądź nie, Ślązaków za odrębną grupę etniczną bądź narodową?

\section{Dr Waldemar Szendera (Zwiazek Górnoślaski)}

Proszę państwa reprezentuję Związek Górnośląski, który jest najstarszą organizacją na Śląsku, która zajęła się Sląskiem, a w zasadzie taką pozostałością na Górnym Śląsku, który w przeszłości był bardziej kolorowy. Jeżeli chodzi o tak postawioną tezę, czy istnieje naród śląski czy nie, bardzo często, bardzo wielu polityków w Polsce odpowiada, że nie ma takiego precedensu na świecie żeby narodowość śląska w jakikolwiek sposób była uznana, czy pokazywana jako grupa, która w jakikolwiek sposób się odróżnia od innych. Tutaj dziękuję pani doktor Szyszlak za przybliżenie tej czeskiej strony narodowościowej i pokazanie, że w konstytucji Republiki Czeskiej zapisano wyraźnie, że państwo czeskie jest tworzone przez ludzi, którzy są Czechami, Morawianami i Ślązakami. Jak państwo przyjrzycie się godłu czeskiemu, to zobaczycie w nim te wszystkie atrybuty, które tym narodowościom są przypisane, jest lew czeski, jest orzeł morawski i jest piastowski orzeł śląski. Tak więc jakieś przesłanki do uznania Ślązaków za naród są. W związku z tym zapytałem bezpośrednio w ministerstwie spraw wewnętrznych Republiki Czeskiej jak należy rozumieć sformułowanie ludzie, którzy są Ślązakami, czy to jest naród? Padła odpowiedź bardzo prosta tak, należy rozumieć to jako naród, ale żebyśmy nie byli zbyt daleko idący w formułowaniu wniosków w dyskusji toczącej się na ten temat w Polsce. Ci ludzie, którzy określają się jako Ślązacy w Czechach, to nie ci sami ludzie, którzy określają się jako Ślązacy w Polsce, to są ludzie, którzy władają zwykle językiem czeskim i którzy zamieszkują na dzień dzisiejszy trzy powiaty, pozostałości po 
powiecie hluczyńskim, pozostałości po dawnym dużym powiecie nyskim i fragmenty powiatu kłodzkiego. Czyli to są ludzie, którzy tak naprawdę ze śląskością polską mają niewiele do czynienia. Nie mniej jednak ludzie ci, w przeszłości, w czasach austro-wegierskich pokazywali swoją odrębność narodową i podkreślali swoje różnice w stosunku do tych Ślązaków, którzy zamieszkują duży dawny powiat cieszyński, którego ludność określała się jako Polacy. I to jest cała różnica. Druga przesłanka o tym, że była mowa w polityce światowej o tym, że istnieje naród śląski, to jest informacja, która zastała przekazana przez świętej pamięci doktora Karola Śitko, republikanina amerykańskiego, żorzanina z pochodzenia, czyli tak naprawdę mojego sąsiada, który po powrocie w latach 90., już na starość do Polski stwierdził, że śląskość była reprezentowana w ONZ. Pytałem jak to możliwe? Okazuje się, że delegacja Stanów Zjednoczonych ma prawo do reprezentowania narodów, które nie są reprezentowane w żaden sposób na arenie międzynarodowej. Kogo dotyczyła reprezentacja Ślązaków przez Amerykanów. Dotyczyła ona tych mieszkańców Prus, którzy wyjechali, wyemigrowali do Stanów Zjednoczonych przed powstaniem Polski w 1922 roku na Śląsku. Tak więc przesłanki dotyczące istnienia narodowości śląskiej możemy znaleźć, jeśli tylko będziemy dobrze szulkać. W związku z tym argument, że nigdzie w świecie nie została uznana narodowość śląska, moim zdaniem możemy uznać za fałszywy. Natomiast wybór czy chcemy być narodem należy już do nas, to nasze pokolenie zadecyduje o tym czy zechce tworzyć zręby narodowe, czy może mniejszości etnicznej. Część moich kolegów w Związku Gómośląskim mówi, że na Śląsku to my wcale nie jesteśmy mniejszością, my tam jesteśmy większością.

Piotr (Pejter) Długosz (Stowarzyszenie Osób Narodowości Ślqskiej)

Ja odwołam się do innej filozofii czy koncepcji. Można oczywiście przytaczać kolejne argumenty historyczne, zaczynając od Anzelma Ephorinusa, który już w XV wieku pisał do Erazma z Rotterdamu Sielsius non Polonus, ale uważam, że główną tezą, która przemawia za tym, że Ślązacy są odrębną grupą narodowościową - o tym czy etniczną, czy narodową to jeszcze za chwilę powiem - jest sama wola Ślązaków. W końcu mamy kilka spisów powszechnych, dwa w Polsce i spis w Republice Czeskiej, przeprowadzony jeszcze bodajże w czasach Czechosłowacji, gdzie ta grupa się ujawniła. W Polsce mamy wyraźny przyrost tej ludności, gdzie prawie 400 tys. osób uznało tę deklarację w spisie z 2011 roku jako pierwszą. Oczywiście do worka Ślązacy nie można wrzucać wszystkich. Ja uważam śląskość jako kategorię regionalną, bo mamy tutaj przedstawicieli śląskich Niemców, w osobach pana Honki i pana Brehmera, mamy polskich Ślązaków, w osobie pana wicewojewody śląskiego Piotra Spyry no i jest ta grupa, która w ostatnich latach jest najbardziej widzialna, czyli osoby narodowości śląskiej. Dyskutowana jest tutaj kwestia czy Ślązacy mają być uznani na odrębną grupę etniczną czy narodową? Ja uważam, że jeśli założymy, że narodowość w rozumieniu prawa to grupa etniczna czy narodowa, to grupa bezpaństwowa i jeśli przyjrzymy się polskiemu prawu i je zaakceptujemy, a ja uważam że nie ma żadnych przeszkód żeby tak czynić, to rzeczywiście Ślązacy powinni zostać uznani za mniejszość etniczną gdyż nie istnieje żadne państwo na świecie, które ma w nazwie zwrot Śląsk. Czyli raz jeszcze uważam, że mniejszość etniczna, to narodowość bezpaństwowa.

\section{Diethmar Brehmer (Niemiecka Wspólnota Pojednanie i Przyszlość)}

Panie Przewodniczący, Szanowni Państwo, proszę mi pozwolić na pewną refleksję. Otóż 25 lat temu w Poznaniu została zorganizowana przez Instytut Zachodni dyskusja na temat mniejszości narodowych dzisiaj ma swój rozkwit. Chciałbym z całą mocą podkreślić znaczenie w dziedzinie stosunków polsko-niemieckich pani profesor Anny Wolf-Powęskiej z Instytutu Zachodniego oraz pana profesora Andrzeja Saksona. Chciałbym również wspomnieć o panu ministrze spraw zagranicznych Krzysztofie Skubiszewskim, który rozpoczął ten proces jakby artykulacji mniejszości niemieckiej zapraszając naszą delegację na podpisanie traktatu polsko-niemieckiego w Bonn. Jeszcze jedno nazwisko, pan premier Łączkowski, to wszystko poznaniacy. Premier Łączkowski, który rozpoczął i skończył z nami rozmowy na temat odszkodowań, na temat zaliczenia do lat 
wysługi rentowych - co było wówczas i dziś też tak byłoby ocenione jako sensacja - służby w Wehrmachcie. Dla nas to było jakby zakończenie wojny, dopiero wtedy. Proszę państwa pytanie jest takie, że kolegom lepiej będzie udzielić na nie odpowiedź. Ja bym wskazał na pewne genetyczne uwarunkowania Ślązaków. Otóż proszę państwa gdziekolwiek popatrzymy na Górnym Śląsku, to pierwszą rzeczą jest wrażenie, że my jesteśmy wychowani przede wszystkim jako Polacy, dopiero później wychodzi z nas ta śląskość. Gdyby zapytano tych Ślązaków w okresie kiedy ja chodziłem do szkoły podstawowej o to kim są, to większość podobnie jak moja mama odpowiadała, że jest Ślązaczką, ta śląskość jest tam bardzo głęboka. Posłużę się tutaj cytatem Josefa von Eichendorfa, który przepięknie uwydatnił tą istotę w stwierdzeniu wiele „Gedanken verdenkt werden”, wiele myśli zostanie stłamszonych, również myśli o naszej małej ojczyźnie o Górnym Śląsku. Pewnego czasu miłość do tej ojczyzny i tęsknota za nią wybuchnie z pradawną siłą. Jest to ważne w poszukiwaniu odpowiedzi na zadane pytanie czy jest to, czy nie jest grupa etniczna, ale na pewno jest to trwała grupa kulturowa.

\section{Prowadzący, dr Cezary Trosiak}

Panie Przewodniczący możemy więc powiedzieć, że jest to swego rodzaju spotkanie po latach. Gdyż na sali znajduje się trzech uczestników spotkania, o którym był pan łaskaw wspomnieć. Jednym z jego współorganizatorów był pan profesor Andrzej Sakson, wówczas wicedyrektor Instytutu Zachodniego, ja miałem przyjemność być sekretarzem tego spotkania. Przypominam sobie jaka gorąca była atmosfera dyskusji towarzyszącej sporowi o uznanie istnienia w Polsce mniejszości niemieckiej. Można ją porównać z dyskusją jaka dziś towarzyszy uznaniu faktu istnienia na Górnym Śląsku śląskiej mniejszości etnicznej, czy w bardziej radykalnej wersji, mniejszości narodowej. Dziś temperatura dyskusji o mniejszości niemieckiej wyraźnie spadła, czego należy życzyć ślązakowcom. Proszę o zabranie głosu pana wicewojewodę.

\section{Piotr Spyra (Ruch Obywatelski Polski Górny Ślqsk)}

Swoją wypowiedź chciałbym podzielić na dwie części. W pierwszej części na zadane pytanie chcę udzielić odpowiedzi z perspektywy osobistej, gdyż jestem, jak wszyscy zebrani tu koledzy, Górnoślązakiem, moja odpowiedź brzmi jednoznacznie nie. To znaczy Ślązacy nie są odrębną grupą etniczną, nie są odrębną narodowością, nie są odrębnym narodem. Takie jest moje doświadczenie rodzinne, takie jest moje widzenie tradycji tożsamości śląskiej. Oczywiście można sobie wynajdywać różne anegdoty, że gdzieś, ktoś, ileś tam lat temu coś powiedział, natomiast jeżeli realnie popatrzymy na nasze śląskie dzieje, jeśli popatrzymy na wybory Ślązaków na ostatnie dziesięciolecia, to mogę z czystym sumieniem powiedzieć, że nie ma podstaw żeby taką narodowość śląską wykreować. To jest moje osobiste zdanie jako Gónoślązaka i jednocześnie odpowiedź na zadane pytanie. Nie widzę w swoich życiowych doświadczeniach przesłanek ku temu żeby taką tezę postawić. Jeżeli spojrzymy na to szerzej, każdy bowiem może spojrzeć na to inaczej, ja mówię o swoim osobistym doświadczeniu, jeżeli na to spojrzymy szerzej z punktu widzenia prawnego, z punktu widzenia naukowego, spróbujemy to w jakiś sposób zdefiniować, to moim zdaniem są dwie możliwości. Jeżeli weźmiemy obecną tradycję intelektualną polska, choć zdaję sobie sprawę, że znaczna część panelistów odrzuca te tradycje, jeżeli weźmiemy pod uwagę polską tradycję intelektualną, jeżeli weźmiemy stan polskiego prawa aktualnie, no to też nie ma przesłanek ku temu żeby narodowość śląska została uznana. Takie jest moje zdanie. Natomiast jeśli odrzucimy jakakolwiek próbę definiowania narodu i obiektywizowania tego i uznamy woluntarystycznie, że narodowość czy grupa etniczna, to jest tylko i wyłącznie kwestia woli, to oczywiście taka sytuacja w pewnym sensie zaistniała, pojawili się ludzie z odrębnym poczuciem tożsamości. Przy czym, i to jest moim zdaniem ważny przyczynek do tej dyskusji, to jak dostosować do tej sytuacji obecny system prawny Polsce i obecne definicje w języku prawnym, które dotyczą tych pojęć, o których rozmawiamy. I moim zdaniem jest takie rozwiązanie i tym rozwiązaniem jest model francuski, którego istota zawiera się w przyjęciu założenia, że jest jeden naród obywatelski i jest to całkowicie niezależne od wyborów obywateli. 
Dr Jerzy Gorzelik (Ruch Autonomii Ślqska).

Chciałoby się przypomnieć, że ta francuska obojętność w sprawach tożsamościowych przejawiała się rządów Charlesa de Gaulle'a wywieszaniem w szkołach tabliczek zabrania się pluć na podłogę i mówić po bretońsku. Gdybyśmy się zastanowili nad doświadczeniami czy wyborami Ślązaków, o których tutaj pan wojewoda mówił w ostatnich dziesięcioleciach, to zapewne doszlibyśmy do wniosku, że najczęstszym wyborem był wyjazd do Republiki Federalnej Niemiec. Nie wiem czy z tego można wyciagać wnioski, które pomogą nam dojść do konkluzji w tej dyskusji. Natomiast odpowiedź na pytanie, które zostało przed nami postawione, powinna uwzględniać dwie płaszczyzny, z jednej strony możemy się zapytać o status Górnośąlzaków na płaszczyźnie tej nauki, jakąjest choćby socjologia, z drugiej strony możemy się zapytać o to jakie miejsce należy przyznać Ślązakom w systemie prawnym. My mówimy tutaj na przykład o narodowości, która bywa różnie rozumiana, niektórzy ją definiująjako przynależność do narodu, inni mówią, że jest to inna forma wspólnoty, protonaród bezpaństwowy, ale przypomnę, że w tym drugim tego słowa znaczeniu polski system prawny tym pojęciem się nie posługuje, z jednym wyjątkiem, czyli ustawy o spisie powszechnym, gdzie narodowość jest definiowana jako kwestia poczucia jednostki, a więc jako kwestia subiektywna. Dlaczego Ślązaków można uznać za narodowość czy naród? Tu nie będę rozstrzygał sporu między różnymi szkołami, które spierają się co do tego rozróżnienia. Odwołując się do teorii Benedicta Andersona można powiedzieć, że Górnoślązacy są wspólnotą wyobrażoną, spora część z nas, oczywiście nie wszyscy, ale ci którzy deklarują narodowość śląską wyobraża sobie nas jako wspólnotę czy to o charakterze narodowym, czy protonatodowym. Większość z nas nie dysponuje taką wiedzą aby dokonać takiej dystynkcji. My akurat za tym stołem, wszyscy się znamy, ale gwarantuję państwu, że zdecydowana większość tych osób, które w dwóch spisach ludności zadeklarowała narodowość śląska, to nie są moi znajomi, mimo że niektórzy w to wątpią. Zatem jest to niewątpliwie wspólnota wyobrażona, co więcej, jest to wspólnota, którą charakteryzuje świadoma wola, która przejawia się w rozmaitych działaniach podejmowanych przez tych Górnoślązaków, którzy dystansują się i od niemieckich i polskich deklaracji narodowych, co nie oznacza dystansowania się od tych elementów kultury, które również w tożsamości górnośląskiej występują. Ta świadoma wola przejawia się również w inicjatywie obywatelskiej, mianowicie w popartej przez sto czterdzieści cztery tysiące obywateli Rzeczpospolitej Polskiej inicjatywie nowelizacji ustawy o mniejszościach narodowych i etnicznych oraz o języku regionalnym. Bez wątpienia możemy powiedzieć, że nasza wspólnota ma swoje własne mity i swoje symbole, i swoją własną narrację historyczną. Ta narracja niejednokrotnie jest płaszczyzną sporów między nami i tymi Gornoślązakami, którzy przyjęli polską bądź niemiecką narrację historyczną, takim symbolem pozostaje wojna, dla nas wojna domowa 1921 roku, dla Niemców polskie powstanie, bądź polska akcja dywersyjna na Górnym Śląsku, a dla Polaków po prostu III powstanie śląskie.

\section{Prowadzący, dr Cezary Trosiak}

Proszę Państwa tytułem informacji chciałbym powiedzieć, że potencjalnych uczestników tej dyskusji na Górnym Śląsku jest bardzo wielu. Jednak organizatorzy musieli dokonać jakiegoś wyboru. Oprócz przedstawicieli organizacji, którzy są obecni na sali, zaproszenie wystosowaliśmy również do „Niemców opolskich”, czyli do Towarzystwa Społeczno-Kulturalnego Niemców na Śląsku Opolskim, osobiście odbyłem rozmowę na ten temat z posłem Ryszardem Gallą. Do samego końca liczyliśmy, że przedstawiciel tej organizacji, która jest przecież bardzo ważnym podmiotem w dyskusji na temat tożsamości górnośląskiej pojawi się na naszej konferencji. To tyle tytułem wyjaśnienia, które powinienem na początku poczynić. Kontynuując naszą dyskusję chciałbym abyśmy skoncentrowali się obecnie na poszukiwaniu odpowiedzi na pytanie; jak ustawa rozwiązuje problemy, z którymi spotykamy się na Górnym Śląsku, jakie kwestie zostały rozwiązane, a jakie oczekują na rozwiązanie? 


\section{Dr Waldemar Szendera}

Tak naprawdę to państwo odpowiadacie przez cały czas na to pytanie, ja jestem również naukowcem, ale przyrodnikiem, w związku z tym jest mi trudno w jakiś sposób nawiązać właściwy poziom rozmowy w tym zakresie. Niemniej jednak należy wyraźnie stwierdzić, że dla takiej organizacji jak Związek Górnośląski i naszych członków ta ustawa, czy te ustawy na razie nic nie wniosły. Po prostu nie potrafimy w jakiś sposób znaleźć odpowiedzi na to czy możemy zajmować się śląską grupą etniczną, czy narodem śląskim? Dla nas zapisy ustawy są bezpodstawne do tego żeby w ogóle o tym dyskutować. Można oczywiście dyskutować o tym na takim poziomie jak państwo to dzisiaj robicie, na poziomie naukowym, natomiast nas interesuje strona praktyczna tego co wynika z zapisów tej ustawy. Dlatego musimy rozmawiać z członkami naszego związku, gdyż są oni bardzo spolaryzowani w swoich poglądach. Poglądy członków w Związku Górnośląskim można by scharakteryzować w taki sposób, że są to ludzie bardzo mocno związani z opcją polską na Gómym Śląsku, najsilniejsza jest opcja śląska na Śląsku i na samym końcu znajdują się nasi członkowie, którzy wnoszą pewien bagaż czeski czy nawet morawski. Oczywiście są również członkowie, którzy reprezentują tożsamość niemiecką w tożsamości górnośląskiej. Ponieważ tak rozmieszczony jest Związek Górnośląski, że jego koła są zarówno w województwie śląskim jak i opolskim, że nasi członkowie, w zależności od tego skąd pochodzą tak rozumieją swoją postawę, rozumieją swoją możliwość skorzystania z ewentualnej ustawy o narodowości czy z ustawy o języku regionalnym. Jest stała dyskusja na forach Związku Górnośląskiego jak znaleźć się w tym wszystkim. Ta dyskusja trwa od wielu lat. W naszym statucie zapisano, że jest ona kwintesencją życia i funkcjonowania Związku Górnośląskiego. W momencie kiedy uzyskamy sprawne narzędzie, sprawną ustawę czy to o języku, czy to o narodowości będziemy w stanie podjąć decyzję o tym, w którym miejscu jesteśmy.

\section{Piotr (Pejter) Dlugosz}

Patrząc na Górny Śląsk i ustawę o mniejszościach narodowych i etnicznych oraz języku regionalnym, to ta ustawa załatwiła lepiej lub gorzej sprawy śląskich Niemców. Jeśli chodzi o osoby narodowości śląskiej, to ja powiem, że ona pogorszyła sytuację osób, które deklarują narodowość śląską co najmniej z dwóch powodów. Pierwszy, od momentu gdy znalazła się tam zamknięta lista uznanych prawnie narodowości grup etnicznych i społeczności używających języka regionalnego wszystkie sądy, rozstrzygające wnioski grup regionalnych o uznanie praw do traktowania ich jako odrębnej grupy etnicznej, powołują się na zapisy tej ustawy. Jeśli nie ma was w ustawie, to nie możecie tworzyć organizacji z nazwą narodowość śląska. Więc z tego powodu nam utrudniła poruszanie się w kategoriach prawnych. Też utrudniła nam staranie się o środki zewnętrzne, Stowarzyszenie Osób Narodowości Śląskiej czy inne organizacje regionalne, w których brałem udział skarżą się, że dopóki nie było tej ustawy mogliśmy wnioskować o środki na działania na rzecz szeroko rozumianej tożsamości powołując się na tożsamość śląską i to zależało od dobrej czy złej woli urzędnika, który rozstrzygał przyznanie tych środków. Teraz sprawa jest zamknięta nie możemy w żadnym grancie startować i powołać się na naszą mniejszość etniczną lub grupę narodowościową, ponieważ nie ma nas w ustawie. W związku z powyższym nie przysługują nam żadne środki z tego tytułu. Z mojej prywatnej perspektywy czy osób reprezentujących narodowość śląską ta ustawa zdecydowanie pogorszyła sytuację.

\section{Diethmar Brehmer}

Ze strony niemieckiej wspólnoty na Górnym Śląsku ustawa ta nie ma dla nas praktycznie żadnego znaczenia. Niczego nam nie daje ani niczego nam nie odbiera. Mniejszość niemiecka opiera się na traktacie polsko-niemieckim, który wskazuje co możemy zrobić a czego nie, a jeszcze szczegółowiej traktat mówi do czego jesteśmy predystynowani. Jeśli cokolwiek chcemy zrobić, założyć jakąś organizację wykonać jakieś działania, to musimy patrzeć na zapisy traktatu. Inna sprawa, że finansowanie naszej organizacji przez budżet państwa w skali roku, to kwota 4 tys. złotych, to jest kwota, która jest przeznaczona na działalność chóru. Należy zaznaczyć, że członkowie chórów tak szybko się sta- 
rzeją, że niedługo i tę działalność będziemy musieli skończyć. Szanowni państwo, mniejszość niemiecka, czy raczej Niemcy na Górnym Śląsku nie opierają swojej działalności tylko na prawie powojennym. Mniejszość niemiecka na polskim Górnym Śląsku istnieje od 1922 roku, w związku z tym ma doskonałe tradycje, które chcemy kontynuować. Dobrze by było, aby władze polskie dowiedziały sięjak wyglądała dawniej ta współpraca i nawiązały do tej tradycji. Przypominam, że funkcjonowanie mniejszości niemieckiej regulował tzw. „mały traktat wersalski” i do tej tradycji chcemy nawiązywać. Dokument ten był wzorem do regulowania relacji między Niemcami a mniejszością duńską w Niemczech po I wojnie światowej. Na tej podstawie również tworzono zapisy traktatu polsko-niemieckiego w obszarze mniejszość niemiecka w Polsce i mniejszość polska w Niemczech.

\section{Piotr Spyra}

Zaczął bym od tego, że tutaj w tych dwóch stanowiskach, które się zarysowały na temat tego czy dała nam coś ustawa czy nie, to ja tutaj zgadzam się z panem przewodniczącym Długoszem, natomiast nie zgadzam się z panem przewodniczącym Berhmerem. Uważam, że właśnie jeśli chodzi o mniejszość niemiecką, to ta ustawa dużo nam dała jeśli chodzi o utrzymywanie szkolnictwa, sytuację szkół niemieckich w Polsce. Marzę o tym jako Polak, aby ta ustawa stała się wzorem do rozwiązywania problemów szkolnictwa dla mniejszości polskiej w Niemczech, żeby Niemcy przywrócili te przywileje, które mniejszość polska w Niemezech miała do roku 1939. To jest oczywiście uwaga na marginesie. Odpowiadając wprost na zadane pytanie, to osobiście uważam tę ustawę za dobrą, nie oczekuję jak większość zebranych tu dyskutantów, aby ustawa ta dała dialektowi śląskiemu czy też gwarom śląskim status języka regionalnego. Posługuję się gwarą jakkolwiek to śmiesznie brzmi, w trakcie świąt rodzinnych godomy po śląsku. Jednak uważam, że nie ma co mnożyć bytów ponad konieczność, gwary śląskie są takie jakie są, próba tworzenia języka na bazie dialektu śląskiego czy gwar śląskich byłaby bardzo sztuczna. Jeden bardzo mały przykład, kolega przewodniczący przybrał sobie imię Pejter, natomiast w mojej rodzinie w okolicy Pszczyny nikt Piotrowi nie mówiłby Pejter tylko Pioter. Takich przykładów można by mnożyć wiele. Mam też dużą nieufność, i to powiem szczerze mimo, że w tym gronie może to zabrzmieć przykro jako, iż zauważyłem jedną rzecz, że robi się pewną podbudowę ideologiczną dla ewidentnie politycznej akcji. Jest to swoista forma rewizjonizmu, w tym przypadku pojęciowego czy językowego, który wykorzystywany jest do celów politycznych. Bardzo często, nawet analizując publikacje czy też pewne trendy w badaniach naukowych można zauważyć, że z roku na rok redefiniuje się w językoznawstwie czy w etnologii pojęcia naród, narodowość. Zjawisko to wywołuje poczucie braku ufności do tych podbudów, które się do tego celu tworzy.

\section{Dr Jerzy Gorzelik}

Ja chciałem zauważyć, że bez rewizjonizmu nie ma nauki tak naprawdę. Wróćmy do meritum. Co do ustawy, to można ją postrzegać jako pewien krok naprzód w stosunku do stanu sprzed jej uchwalenia, ale jak się dzisiaj zresztą przekonaliśmy podczas sesji plenarnej naszej konferencji ustawa ta niesie ze sobą szereg niebezpieczeństw. W tym miejscu chciałbym zwrócić uwagę na takie dwie płaszczyzny. Oczywiście ta ustawa jest wykluczająca nie tylko dla Ślązaków ona jest wykluczająca także dla takich niewielkich grup historycznie ze Śląskiem powiązanych jak choćby użytkownicy języka wilamowskiego. Język wilamowski nie otrzymał żadnej ochrony prawnej na gruncie tej ustawy. Można by powiedzieć to jest szczegół, który można by naprawić, jednak na razie takiej woli nie widzę, ale ten szczegół daje nam wyobrażenie o tej ideologii, o której mówi pani profesor, którą należy dostrzec pod tekstem ustawy. Ta ideologia, to lekceważenie słabych i tych, którzy nie potrafią upomnieć się na gruncie politycznym o swoje prawa. Wspólnota wilamowska jest tak nieliczna, że możemy mówić o sytuacji przypominającej tę na wyspie Man pod koniec pierwszej dekady XXI wieku, kiedy język manx został uznany za język martwy. Całe szczęście po paru latach doprowadziło to do gwałtownego renesansu, swoistego odbicia i społecznej mobilizacji. Oby tak było również w przypadku języka śląskiego. Chciałbym zwrócić uwagę na pewną logi- 
kę, w której mieści się ta ustawa. Jest to logika państwa narodowego, które kryje się za nacjonalizmem obywatelskim, za ustawą zasadniczą Rzeczypospolitej Polskiej, ale tak naprawdę jest nacjonalizmem etnicznym. Choćby ustawa o języku polskim - jest wyrazem nacjonalizmu stricte etnicznego. Proszę zwrócić uwagę, że w tym systemie grupa, która poczuwa się do odrębności kulturowej, do własnej tradycji, a nie jest ujęta w ustawie poddana jest absolutnej nieuchronnej asymilacji na gruncie systemu szkolnictwa. W przypadku odrębnych grup etnicznych takie zjawisko nazywa się etnocydem i ten etnocyd wobec grup etnicznych w Rzeczpospolitej Polskiej jest uprawiany. To oczywiście brzmi groźnie, choć nie wiąże się ze stosowaniem przemocy tylko z pozbawieniem jakiej grupy jej tożsamości metodami, które ja nazywam bezwładem biurokratycznym. Nie przypisuję bowiem nikomu świadomej woli by dokonywać tak konsekwentnej homogenizacji kulturowej, raczej mamy tu do czynienia z pewnym brakiem refleksji i bezwładem. $Z$ tego punktu widzenia mogę stwierdzić, że w przypadku grupy śląskiej, tej która definiuje się w kategoriach odrębnej narodowości ta ustawa nie załatwia niczego, natomiast jest impulsem do społecznej mobilizacji, która na Górnym Śląsku ma miejsce. Tak więc być może mimo woli ustawodawca sprawie śląskiej w sposób niezamierzony się przysłużył.

\section{Prowadzący, dr Cezary Trosiak}

Proszę Państwa i trzecie pytanie, które jest chyba najbardziej gorące, jeśli chodzi o pytanie dotyczące kwestii tożsamości górnośląskiej, to pytanie które zahacza o kwestie związane z separatyzmem. Najbardziej radykalni przeciwnicy tej dyskusji mówią, że może ona być wstępem do pojawienia się zjawisk, z którymi mamy teraz do czynienia we wschodniej Ukrainie. Tak więc prosimy naszych gości do ustosunkowania się do następującej tezy: uznanie Ślązaków za odrębną grupę etniczną (narodową) będzie początkiem procesu, w wyniku którego dojdzie do pojawienia się dążeń separatystycznych w tym regionie Polski. Oczywiście Górny Śląsk składa się z zachodniej i wschodniej części, czyli z województwa opolskiego i województwa śląskiego.

\section{Dr Waldemar Szendera}

Pytanie jest podszyte już w samej treści pewnym strachem, który na Śląsku towarzyszy nam od zakończenia wojny trzydziestoletniej. Tak naprawdę na Śląsku boimy się separatyzmu, boimy się potraktowania nas jako ludzi z jednej strony drugiej kategorii i z innej strony jako ludzi, którzy mają jakieś inne aspiracje. Wielu członków Związku Górnośląskiego widzi właśnie ten strach również interpretując w ten sam sposób trzy powstania śląskie, które w swoim zrywie tak naprawdę niewiele dały, dały dużo krwi, która została przelana po obu stronach śląskiej granicy podzieliła trwale Śląsk. Podział ten jest utrwalany przez kolejne państwa, które przychodzą na ten teren, czyli w okresie międzywojennym druga Rzeczpospolita w czasie wojny III Rzesza, następnie „Polska Ludowa” i obecnie „Trzecia Rzeczpospolita” w zasadzie każde z tych państw utrwala ten podział, który budzi w nas lęk. Przy uznaniu Ślązaków jako odrębnej narodowości ten lęk może być wzmocniony bądź osłabiony, przede wszystkim da poczucie tej części mieszkańców Górnego Śląska, która mieszka na pograniczu województwa opolskiego i śląskiego podstawę do tego, aby poczuć się jednym narodem. To jest jak gdyby jedno wyjście. Natomiast czy rozwiąże to sprawy polskiego nacjonalizmu na Śląsku, ponieważ tak należałoby na tę sprawę popatrzeć, że jesteśmy stale uwikłani nie tylko w rozumienie Śląska i śląskości jako odrębnej narodowości, ale jesteśmy również uwikłani w bardzo silny polski nacjonalizm, szczególnie w tych miejscowościach, które w latach 70. zostały zdominowane przez ludność pochodzenia polskiego w dużych miastach, takich jak na przykład Jastrzębie, Żory, Rybnik. To miasta, które etnicznie do tej pory były na pewno bardzo związane z myślą śląską i śląskością jako taką, natomiast po przewartościowaniu ludnościowym polski nacjonalizm spowodował, że znaczna część ludności tych obszarów albo wyjechała do Niemiec, albo uległa przyspieszonej polonizacji. Stworzyło to sytuację, w której śląskość jako taka już się w tych miejscach nie odrodzi jak chcieliby koledzy z Ruchu Autonomii Śląska czy Związku Ludności Narodowości Śląskiej. Niestety to już jest stracone. 


\section{Piotr (Pejter) Długosz}

Zanim odpowiem na to pytanie, to taka anegdota, która dobrze pokazuje tę sytuację. Na Śląsku było kilka prób zarejestrowania organizacji z nazwą narodowość śląska i bodajże dziesięć lat temu w Katowicach próbowano zarejestrować Śląski Ruch Narodowy. Zostało to odrzucone inicjatorzy poszli z tym samym statutem tylko zmienili nazwę na Śląski Ruch Separatystyczny i o dziwo sąd to zarejestrował. Inicjatorzy byli tak zdziwieni tą całą sytuacją, że po trzech latach zwiesili działalność i rozwiązali stowarzyszenie. Sytuacja ta pokazuje jak bardzo się polskie władze boją, jak bardzo i my boimy się na Śląsku nazwy narodowość śląska jako przejawu separatyzmu. Natomiast jeśli chodzi istotę tego pytania, to ja uważam, że byłoby wręcz przeciwnie. W tej chwili brak jest dyskusji przede wszystkim z grupą osób narodowości śląskiej, pomimo że kilkakrotnie pisaliśmy do sejmu, czy to do prezydenta, czy rzecznika praw obywatelskich w sprawie spotkania, umówienia się, czy do komisji wspólnej rządu i mniejszości i zawsze dostajemy krótką odpowiedź-nie ma was w ustawie, z wami nie rozmawiamy. Takie działania, czy rozwiązywanie kolejnych stowarzyszeń budzi w wielu osobach poczucie odrzucenia, a przez to budzi tendencje separatystyczne. Poprzez danie praw Ślązakom Polska miałaby szansę stać się pierwszym państwem, które by taką organizację $\mathrm{z}$ nazwą narodowość śląska uznało. Polska nie skorzystała $\mathrm{z}$ tej szansy $\mathrm{i} w$ tej chwili każde kolejne działanie, gdzie nie ma żadnej dyskusji, gdzie nie ma żadnego dialogu powoduje narastanie tendencji, które można nazwać separatystycznymi. Te odczucia nie przerodzą się w żaden ruch separatystyczny, mam przynajmniej taką nadzieję, ale jeśli ktoś jest winny za pojawianie się tego typu tendencji, to są to nieprzemyślane decyzje strony większościowej.

\section{Diethmar Brehmer}

Proszę państwa, ja przez cały czas mówię z punktu widzenia naszej organizacji. Gdybym miał się wypowiadać generalnie o sprawach górnośląskich mówił bym troszeczkę inaczej. Strach przed Śląskiem, to jest strach przed Niemcami, to jest sprawa dla nas absolutnie jasna. Poza tym strachem jest jeszcze strach przed tym, że jednak przepraszam nie chcę nikogo obrazić, że Śląsk jest solidny, jest pracowity i tak dalej i gdyby doszło do jakiegoś odłączenia to Polska straciła by ekonomicznie na rzecz Niemiec. Tu raz jeszcze chciałbym podkreślić rolę pani profesor Anny Wolf-Powęskiej, która przedstawiała relacje polsko-niemieckie na gruncie prawdy. Również o tym co do tej pory było przemilczane, a więc o tej tragedii górnośląskiej, która proszę państwa - to trzeba sobie jasno powiedzieć - dotyczyła górnośląskich Niemców, ale nie tylko górnośląskich, dotyczyła Niemców mieszkających w przedwojennej Polsce. Na ten temat nie będę się rozwlekał, ale ten strach wynika z tego, że, przepraszam jeśli ktoś poczuje się urażony tym co powiem, jest jakaś obawa, że Polacy mogą się poczuć winni za te strawy związane z latami po 1945 roku. Proszę państwa ja sobie doskonale przypominam czasy listów biskupów polskich do biskupów niemieckich, co się wtedy działo. Młodzi uczestnicy naszego spotkania nie mogą tego pamiętać, ale to była straszna nagonka na polski episkopat, a przede wszystkim na arcybiskupa Kominka, wybaczamy i prosimy o wybaczenie, otóż my Niemcy na Śląsku oczekujemy chociaż małego gestu, żeby podkreślić, że jednak ten okres był w narodzie polskim okresem tragicznym, chodzi o moralną ocenę wydarzeń jakie miały miejsce między narodem śląskim i narodem polskim po 1945 roku. Po takim moralnym zadośćuczynieniu sytuacja Polski byłaby jakaś bardziej czysta i bardziej moralna. Na to czekamy.

\section{Piotr Spyra}

Mam pytanie panie przewodniczący, czy będziemy mogli wzajemnie sobie zadawać pytanie?

\section{Prowadzący, dr Cezary Trosiak}

Tak, jeśli nam czas pozwoli, to przewidziana jest na to trzecia część debaty.

\section{Piotr Spyra}

Tutaj co prawda padło pytanie o pewien lęk, czy strach przed skutkami tej ewentualnej zmiany ustawy, o czym mówi sam tytuł konferencji, gdzie mówi się o lęku i nadziei. Gdy ja tu reprezentuję 
lęk, a pozostali uczestnicy debaty nadzieję, to czuję się trochę dyskomfortowo w tej roli. Natomiast jeżeli można się czegoś lękać, to tego co ma cały czas miejsce na Śląsku, co jest skutkiem polityzacji i ideologizacji dyskusji na temat tożsamości śląskiej. To jest to co profesor Nijakowski nazwał budowaniem symbolicznych granic etnicznych, to jest to co powoduje, że śląskość kiedyś była taką przystanią przytułkiem dla Ślązaków znajdujących się między różnymi politycznymi, narodowymi, etnicznymi, religijnymi sporami. Jednak na gruncie rodziny śląskość była czymś co jednoczyło i powodowało, że spory były racjonalizowane i nie przekładały się na stosunki i więzi międzyludzkie. Teraz ta śląskość, która jednoczyła jakby ponad polityką, ponad narodowością, ponad religią stała się jedną z opcji narodowych i jedną z opcji politycznych. Tego należy się bać, to jest groźne. Widzę to po dyskusjach toczących się nawet w mojej rodzinie, widzę tego skutki jak się kiedyś rozmawiało przy rodzinnym stole, jak się teraz rozmawia. Pojawiło się symboliczne tworzenie granic na gruncie, który kiedyś łączył ponad granicami etnicznymi to jest rzeczywiście to co jest groźne i czego można się bać.

\section{Dr Jerzy Gorzelik}

Ja przede wszystkim chciałbym nieco prowokacyjnie zadeklarować swoje zdziwienie tym, że w Polsce ktokolwiek może bać się separatyzmu, przecież tego państwa nie byłoby gdyby nie działalność separatystyczna a wschodni Górny Śląsk nie znalazł by się w 1922 roku w granicach II Rzeczpospolitej Polskiej, gdyby nie polski ruch separatystyczny na Górnym Śląsku. Proszę państwa bądźmy konsekwentni. Natomiast rzecz jasna niebezpieczny jest, może nie tyle sam separatyzm, bo z nim można sobie radzić w sposób cywilizowany jak pokazuje przykład Zjednoczonego Królestwa czy Kanady, natomiast problemem jest przemoc, do której może separatyzm, czyli nieumiejętne obchodzenie się z separatyzmem prowadzić. Mamy cały szereg przykładów takich sytuacji, do których podczas tej dyskusji już się odwoływano. Bardzo często przyczyną erupcji tego typu antagonizmów jest nie tyle budowanie tożsamości, które zawsze jest związane z budowaniem granic, bo nie ma tożsamości bez granic, ale absolutyzowanie tych granic i dominacja jednej tożsamości nad drugą, która jest uzyskiwana takimi a nie innymi, często bulwersującymi metodami. I tutaj chciałbym się przyłączyć do tego głosu Piotra vel Pejtra Długosza, tak nawiasem w Niemczech jest Johann, Hans, ale nikt nie twierdzi, że nie ma języka niemieckiego. To uwaga do tych zastrzeżeń dotyczących różnego brzmienia w języku śląskim polskiego imienia Piotr, w których twierdzi się, niebezpieczne jest prawne zaznaczanie swoich praw. To właśnie jest niebezpieczne. Wracam do tego pojęcia etnocydu i edukacji szkolnej, bo wydaje mi się, że to jest ten instrument, który wykorzystywany jest w największym stopniu do asymilowania jednostek o nie polskiej tożsamości a nie uznanej w ustawie. Pięć lat temu opublikowany został taki raport przygotowany przez pracowników Uniwersytetu Śląskiego na temat tożsamości uczniów szkół województwa śląskiego, szkół gimnazjalnych i szkół ponadgimnazjalnych. Raport ten ujawnił tak naprawdę całkowitą nieobecność tradycji kultury Górnego Śląska, historii Górnego Śląska w polskiej szkole i co za tym idzie porażającą nieznajomość górnośląskich historii, mitów, symboli. Konkluzja jest następująca, otóż naukowcy stwierdzili, że poprzez taką politykę edukacyjną, poprzez brak w szkole tego pozytywnego kodu śląskości tożsamość śląska budowana jest na poczuciu wykluczenia, występuje swoisty dysonans poznawezy, inna jest narracja w domu inna narracja w szkole i to prowadzi do frustracji, a może prowadzić wręcz do agresji. Tak więc taka polityka państwa może doprowadzić do wychowania pokolenia górnośląskich separatystów. Jednak to nie jest jedyny czynnik. Dodam, że należy szukać także drugiego czynnika poza tożsamościowego, czyli jest to zapaść cywilizacyjna Górnego Śląska widoczna w tej jego starej przemysłowej części, to jest coś co tak naprawdę jest bombą z opóźnionym zapłonem i z tym się trzeba tak naprawdę liczyć. Ten czynnik w połączeniu ze sprawami tożsamościowymi może dać silną mieszankę wybuchową, taki niebezpieczny ładunek.

\section{Prowadzący, dr Cezary Trosiak}

Jestem przekonany, że uczestnicy naszej dzisiejszej debaty, którzy znają swoje poglądy, gdyż wielokrotnie spotykali się przy różnych okazjach z zainteresowaniem posłuchają jak przedmiot ich 
dyskusji, sporów postrzegany jest poza Górnym Śląskiem, jak widziany jest on z perspektywy wielkopolskiej. Pytanie do sali to pytanie, na ile przedmiot debaty jest istotny dla treści dyskusji na temat współczesnych zjawisk społeczno-kulturowych, politycznych zachodzących w Polsce. Jeszcze inne pytanie, jakie nasuwa się na marginesie tej dyskusji, to pytanie o to na ile dyskutujący przerysowują istotę sporu górnośląskiego? Czy nie należy dyskusji tej zakończyć stwierdzeniem, że każda grupa ma prawo do samodefiniowania się? Proszę o zadawanie pytań, które jak się domyślam będzie poprzedzone kilkoma zdaniami tytułem komentarza do wypowiadanych kwestii, jednak ważne jest abyśmy swoją wypowiedź kończyli jasnym sformułowaniem pytania. Proszę również o wskazanie osoby, czy osób, do których pytanie to jest kierowane. Proszę również, aby zadający pytania przedstawiali się.

Dr Barbara Kotarska Kobzarska-Bar (Wyższa Szkoła Handlowa we Wrocławiu)

To ja będę pierwsza. Ja mam pytanie do szanownych panów liderów, działaczy politycznych, przywódców charyzmatycznych. Proszę wyobrazić sobie taką sytuację, mniejszość śląska znajduje się w ustawie, wiadomo radość, szał eksplozja radości, odkorkowane butelki szampana, następnego dnia kac, a trzeciego dnia trzeba zacząć działać. Jakie są pierwsze działania, jakie panowie podejmujecie? To jest pytanie do wszystkich szanownych panów.

Natalia Dlugosz (Uniwersytet im. Adama Mickiewicza w Poznaniu, językoznawca)

Pierwsza myśl, która przyszła mi do głowy w kontekście tej dyskusji, to nie tylko pytanie, ale i trochę parafraza stwierdzenia pana Brehmera, że może strach przed Śląskiem jest strachem przed Niemcami, a może strach przed Śląskiem jest strachem przed nieznanym? Jest to w zasadzie pytanie do nas wszystkich. Jest to pytanie od Wielkopolanki, która od kilku lat mieszka na Śląsku. Natomiast pytanie do pana wojewody Spyry, jest to właściwie taka myśl, która osadzona jest w silnych argumentach, że mowa o mnożeniu bytów w kontekście aktualnej szeroko rozumianej rzeczywistości językowej nie ma racji bytu, ponieważ badamy te języki obserwujemy je i konstatujemy, że w świecie języki zanikają one się nie mnożą. Istnieje bardzo silna tendencja w tym kierunku, wystarczy spojrzeć na publikacje tutaj z lokalnego podwórka, profesora Iwaszkiewicza ostatnio, które ukazały się w serii Okcydentalizm, z których wynika, że języki zanikały będąz roku na rok zanikać, to zwykle jest proces bardziej długotrwały, jednak na pewno języków w świecie nam nie przybywa. Moje pytanie do pana wojewody skąd ta refleksja o mnożeniu bytów? Druga sprawa jest taka, że bardzo wiele języków ogólnych, języków narodowych, to języki które wyrosły na dialektach i z perspektywy językoznawcy uważam, że bardzo nieuzasadnione jest wartościowanie odmian języków z takiego pułapu.

Dr hab. Helena Duć-Fajfer (Uniwersytet Jagielloński - etnofilolog)

Mam pytanie o język, jeśli pan wojewoda mówi, że w domu rozmawia po śląsku, to jaki jest pana język macierzysty?

Prof. Andrzej Sakson (Uniwersytetu im. Adama Mickiewicza w Poznaniu, socjolog)

Na początek taka refleksja, że gdy mówimy o Śląsku to musimy określić o jakim Śląsku mówimy. Bo ja wyróżniam do celów analitycznych pięć subregionów śląskich. Pierwszy to jest dawne przedwojenne województwo śląskie, tzw. „polski Górny Śląsk”, gdzie ta tradycja śląskości państwa polskiego, autonomii śląskiej, sejmu śląskiego jest zgoła inna niż na tzw. „niemieckim Górnym Śląsku”, czyli terenach, które Polska przejęła po 1945 roku, a popularnie nazywanymi „ziemiami odzyskanymi”, „ziemiami zachodnimi i północnymi”. Czyli to jest generalnie województwo opolskie plus trzy powiaty zabrski, gliwicki i bytomski, to jest inny Śląsk z uwagi na tradycje państwa polskiego, gdyż powiaty te stały się polskie dopiero po 1945 roku. Jeszcze inne klimaty panują w Zagłębiu, to jest ten region Śląska, który do 1918 roku wchodził w skład zaboru rosyjskiego. I mamy czwarty Górny Śląsk, nazywany popularnie Śląskiem Cieszyńskim, gdzie mamy 
fenomen protestancki zawarty w sformułowaniu „twardy Ślązak jak luterska wiara”, gdzie bycie Polakiem oznaczało bycie ewangelikiem, luteraninem i gdzie opcja polska, tożsamość polska inaczej kształtowała się niż na niemieckim czy na polskim Śląsku. Na końcu chciałbym wskazać fenomen tożsamości dolnośląskiej, czyli obecnego województwa dolnośląskiego z jego piękną stolicą Wrocławiem, gdzie nastąpiła po 1945 roku wymiana ludności. Tam mamy do czynienia z tym co na Mazurach nazywa się fenomenem nowej tożsamości mazurskiej, a na Dolnym Śląsku dolnośląskiej, przynajmniej próby jej budowania. Ona jest istotna dla ludzi przybyłych do tego regionu $z$ różnych stron na teren np. Wrocławia, i którzy też chcą się w jakiś sposób zakorzenić w tym mieście, też chcą się identyfikować ze Śląskiem, ze swoim Heimatem, a dla nich jest to Dolny Śląsk. Jeszcze inna sprawa, znana mi z przekazów rodzinnych, lokująca się ponad tymi wszystkimi podziałami, to kwestia Polaków, którzy przybyli z różnych stron na Górny Śląsk, przede wszystkim na ten tzw. „polski Śląsk”, którzy zapuścili tam korzenie i przejmują wartości śląskie, którzy się „ślązaczą", nie wiem czy to jest dobre określenie, ale przejmują wzory śląskie, bo tam mieszka ich drugie czy trzecie pokolenie, którzy nie chcą wracać do miejsc, z których wywędrowali na Górny Śląsk. Pytanie jest takie, czy panowie dostrzegacie tą różnicę, czy to o czym panowie mówicie dotyczy polskiego śląska, czy tego śląska również opolskiego? Moim zdaniem warto to doprecyzować.

Dr Tomasz Wicherkiewicz (Uniwersytet im. Adama Mickiewicza w Poznaniu -językoznawca) Cieszę się, że został do tej dyskusji przywołany przykład położonej w województwie śląskim miejscowości Wilamowice i języka wilamowickiego, gdyż w tej problematyce siedzę po uszy już od 25 lat. Wilamowskość jest takim przykładem, która postrzega śląskość jako pewną ostoję, a nie zagrożenie dla siebie. Działacze wilamowscy, jest już nowe ich pokolenie, postrzegają w śląskości niszę dla swojego języka. Podejrzewam, że powołują się na podobne przykłady jak na przykład niezwykle szerokimi prawami obdarzona enklawa języka arańskiego w Katalonii, która przez to, że znajduje się w Katalonii cieszy się dużo większymi prawami niż cieszyłaby się gdziekolwiek indziej. $Z$ drugiej strony wilamowskość nie jest postrzegana jako zagrożenie, wilamowskość wycierpiała to co wycierpiała tylko dlatego, że była inna. Obojętnie czy w kontakcie z większością polską i czy niemiecką.

Dr Malgorzata Myśliwiec (Uniwersytet Śląski - socjolog, politolog) Mam pytanie do pana wojewody Spyry, gdyż to posądzenie o rewizjonizm krew mi wzburzyło. Chciałabym zapytać pana o następującą rzecz, już w 2002 roku okazało się, że Górnoślązacy są największą mniejszością w III Rzeczpospolitej, mimo to w ustawie z 2005 roku nie występują, pan profesor Janusz wyjaśnił nam to, nie ma takiej woli politycznej, to dlaczego w 2011 roku pozwolono się tej grupie określić?

Prof. Monika Mazurek Janasik (Uniwersytet Gdański - antropolog społeczny)

Mam pytanie również do pana wojewody, ponieważ bardzo zafrapowało mnie, iż w pańskiej wypowiedzi dominuje taka myśl, że z pana doświadezeń rodzinnych wynika, że nie ma czegoś takiego jak naród śląski. Chciałam zapytać na jakiej podstawie pan formułuje ten wniosek mimo, że prawie pół miliona osób twierdzi coś innego? Czyli z ich doświadczeń wynika coś zgoła innego. To mnie zafrapowało na jakiej podstawie pozawala pan sobie na formułowanie tak daleko idącego wniosku?

Prof. Andrzej Sadowski (Uniwersytet w Białymstoku - socjolog)

Chciałbym się podzielić na marginesie toczącej się dyskusji taką refleksją, otóż jak wiadomo ustawa dotychczasowa dzieli społeczeństwo polskie na Polaków, mniejszość niemiecką, ukraińską, białoruską, tak jakby to były oddzielne całości zupełnie ze sobą niepowiązane, wkłada nas w takie szuflady, które wyciagamy, a następnie chowamy, a tymczasem obserwujemy, że Śląsk to piękny pluralizm, każdy z panów reprezentuje jakąś część tego pluralizmu. Tak sobie pomyślałem w tej chwili żebyśmy wyszli z taką super inicjatywą, abyśmy wskazali na sytuację panującą na Górnym 
Śląsku jako na wzorcowy przykład pluralizmu, podobnie rzecz się ma z Białorusinami na Podlasiu, którzy też są wewnątrz zróżnicowani. W efekcie powstaje wielobarwny bukiet wzbogacający kulturę polską.

\section{Prowadzący, dr Cezary Trosiak}

Skorzystam z możliwości, które mają zwykle prowadzący dyskusję i udzielę sobie głosu by zadać dwa pytania. Pierwsze kieruję do pana Jerzego Gorzelika, jakie są szanse, powołania Śląskiej Partii Regionalnej? Z kolei pytanie do pana Pejtera Długosza, na czym polega istota sporu, z jakim mamy do czynienia na terenie województwa opolskiego między Stowarzyszeniem Osób Narodowości Śląskiej a mniejszością niemiecką? Prenumeruję pismo „Wochenblatt.pl”, posiadam niemal wszystkie jego egzemplarze i od mniej więcej 2011 roku wyraźnie zauważalny jest spór, czasem konflikt między tymi dwoma środowiskami. To co wydaje się oczywiste, że ślązakowcy i mniejszość niemiecka na terenie województwa opolskiego powinny ze sobą współpracować na rzecz definiowania i kultywowania tożsamości śląskiej. Dlaczego tak się nie dzieje?

\section{Dr Waldemar Szendera}

Udzielę sobie głosu bo mam mikrofon. Pierwsze pytanie, które padło, to pytanie o to co będziemy robić jak prawo polskie uzna śląską odrębność. Ja nie wiem czy będzie szampan, bo po co, gdyż tak naprawdę nic się nie zmieni, nadal będziemy obywatelami Rzeczpospolitej Polskiej, nadal będziemy płacić te same podatki, nadal będziemy wykonywać swoją pracę uczciwie tak jak to do tej pory robimy, natomiast zyskamy coś co pozwoli nam się ewentualnie dookreślić, i to dookreślenie będzie na tyle stymulujące, że być może część z nas nie wyjedzie do Irlandii czy Wielkiej Brytanii tylko zostanie na miejscu. Będzie mi łatwiej rozmawiać z moimi synami i w jakiś sposób przekazywać im informację o przeszłości mojego dziadka, który walczył w Wehrmachcie i nie będę się tego wstydził. Będzie może prościej i łatwiej rozmawiać przy rodzinnym stole nie tylko ukradkiem o ciotce w Niemczech, która miała trochę inne poglądy niż cała reszta rodziny tylko będziemy o tym mówić w sposób bardziej otwarty i rzeczywisty. Także nie zawsze uzyskanie pewnego dobra, jakim w tym wypadku może być uznanie śląskości będzie manifestowało się tym, że wyjdę na ulicę i będę krzyczał jestem Ślązakiem. Nie, tego nie zrobię i tego nikt z rozsądnych Ślązaków nie zrobi. Po prostu zachowamy to dla siebie, tacy jesteśmy. Będzie to jeden z elementów naszego powrotu do normalności. Czy ten Śląsk to strach przed nieznanym, bo też padło takie pytanie ogólne? Ja myślę, że tak, że wielu ludzi z którymi się spotykam, gdyż na co dzień pracuję w Warszawie obawia się czy nie chcemy być piątą kolumną czy jeszcze jakimiś innymi zielonymi ludkami, bo podobno to jest takie modne w tej chwili. Śląsk jest naprawdę normalną częścią Europy Środkowej, która dobrze komunikuje się z Czechami, Słowakami ma dobre koneksje w tej chwili z Niemcami, a od paru lat coraz lepsze koneksje z Wielką Brytanią i Irlandią. Jednak tak naprawdę ode mnie z domu zawsze się jedzie do Polski. Dla nas ta Polska zawsze będzie miejscem, do którego będziemy dążyć w sprawach zawodowych. Ja mówię po polsku, Polska mnie wykształciła, Polska dała mi to co powinienem dostać, ale również to samo dostałem w Niemczech, gdzie się kształciłem. Moje wykształcenie oparte jest na dwóch filarach, czego życzę każdemu studentowi obecnemu na tej sali. Tutaj padło również pytanie od pani profesor o to jaki jest nasz język. Pani mnie o to nie pytała wprost, ale to samo pytanie, gdyż zadawano mi je parę razy w życiu i w związku z tym odpowiem na nie. Do siódmego roku życia nie mówiłem po polsku, moim językiem rodzinnym, językiem serca był język śląski. Jeden z moich wujków, który pochodził z Krasnegostawu stwierdził, że ten chłopak nie będzie się nadawał do niczego, ponieważ nie potrafi mówić po polsku. Nauczyłem się polskiego najlepiej jak potrafiłem, nauczyłem się również paru innych języków, po prostu było mi łatwiej, znając najpierw śląski, a dopiero później inne języki. Mówiąc już całkiem współcześnie, podział terytorialny i powstanie województwa śląskiego w granicach, które dzisiaj mamy, czyli ziemia górnośląska, trochę ziemi małopolskiej, Śląsk Cieszyński wprowadził olbrzymi zamęt w nomenklaturze śląskiej, szczególnie w moich kontaktach z kolegami 
niemieckimi, którzy zupełnie nie rozumieją o czym do nich mówię, gdy mówię Śląsk. Dla nich Śląsk to jest Wrocław i Dolny Śląsk, natomiast to gdzie my mieszkamy to jest Górny Śląsk. Wprowadzenie jeszcze dodatkowego pojęcia, jakim jest województwo opolskie powodowało, że zupełnie nie było dla nich wiadome gdzie my mieszkamy. W pewnym momencie będziemy musieli w jakiś sensie i tę kwestię uporządkować i doprowadzić do jakiegoś połączenia obu górnośląskich województw. Nie wiem jak to się stanie, ale jest cała część ziemi raciborskiej, która twierdzi to samo, że w sposób sztuczny została oddzielana od Opolszczyzny. Musimy się zastanowié jak tą rzecz uporządkować. Ostatnie pytanie, naród śląski jako naród kulturowy. Bardzo podobała mi się wypowiedź pani profesor Roztropowicz na gali nagród Wojciecha Korfantego, które są nagrodami Związku Górnośląskiego dla zasłużonych mieszkańców Śląska i Opolszczyzny, która powiedziała coś takiego: „Ślązacy są jak Grecy są najlepszymi basztardami na świecie”, to znaczy mieszańcami. Ja o sobie mogę również powiedzieć, że w moich żyłach płynie pewna kropla krwi karaimskiej, czyli najmniejszej mniejszości etnicznej w Polsce. Czyli mamy do czynienia z sytuacją że 54 osoby mają prawo być mniejszością etniczną, a prawie milion Górnoślazaków takiego prawa nie ma.

\section{Prowadzący, dr Cezary Trosiak}

Panie przewodniczący mam nadzieję, że zauważył pan, że w tym momencie gdy mówił pan o połączeniu województw górnośląskich na sali dało się usłyszeć protesty opatrzone komentarzem nie po to walczyliśmy o województwo opolskie. I był to głos przedstawiciela mniejszości niemieckiej $z$ terenu tego województwa. Panie Pejtrze proszę o udzielenie odpowiedzi na postawione pytania.

\section{Piotr (Pejter) Długosz}

Ja się poczuwam do udzielenia odpowiedzi na trzy pytania. Pierwsze działania, powiem tak, nie patrzę na znalezienie się w ustawie jak na skok na kasę, tylko przywrócenie pewnej godności, gdyż od pięciu lat włóczę się po sądach, które mi udowadniają że mnie nie ma, że narodowości śląskiej nie ma. Każda kolejna decyzja sądu zaostrza wydawane wyroki. Pojawiają się w uzasadnieniach takie sformułowania, że przywołują PRL-owską retorykę. Ale nie uciekam od pytania co byśmy zrobili gdybyśmy znaleźli się w ustawie? Już dzisiaj dużo robimy, wydajemy książki po śląsku i o Śląsku, dzieje się dużo rzeczy oddolnych ja obawiam się, że ta ustawa mogłaby cały szereg tych rzeczy zniszczyć, kiedy patrzę co się stało z mniejszością niemiecką w ciagu tych ostatnich dwudziestu lat, której działalność oklapła kiedy przyszły pieniądze dlatego boję się, że to samo może stać się z osobami deklarującymi narodowość śląską. Jednak na pewno są potrzebne środki na działania, które wymagają systematyczności i długofalowego planowania. Czyli przede wszystkim edukacja regionalna i obecność w mediach w języku śląskim, czy działalność dotycząca promowania regionu śląskiego. Tego nie da się dobrze długofalowo robić bez systematycznego i odpowiedniego finansowania. Różnice między Śląskami, przede wszystkim trudno powiedzieć, że Zagłębie to Śląsk, nawet oni się z tym nie zgadzają. Jednak jeśli ktoś parzy na Śląsk całościowo, mimo że widać różnice między częścią cieszyńską i dolnośląską, mimo ze Stowarzyszenie Osób Narodowości Śląskiej powstało w Opolu, to $80 \%$ członków pochodzi z województwa śląskiego co pokazuje, że działamy w obrębie całego Górnego Śląska, gdyż mamy członków również po czeskiej stronie. Mówi o tym ostatnia wydana przez nas książka Dyskretny urok Ślqska jest to książka czeskiej autorki piszącej o kraiku hulczyńskim. Książka ta pokazuje, że ta śląskość jest rozumiana po obu stronach granicy tak samo. I pytanie skierowane tylko do mnie relacja mniejszość śląska mniejszość niemiecka w województwie opolskim. Powiem, że dla mnie jest to kwestia bolesna, bo ja patrzę na śląskość w kategoriach regionalnych i uważam tak samo za Ślązaków przedstawicieli mniejszości niemieckiej czy większości polskiej. Boli mnie to, że z mniejszością niemieckąjest się nam najtrudniej dogadać a od 2002 roku, praktycznie co dwa lata staramy się w województwie opolskim spotkać się z mniejszością niemiecką i dojść do jakiegoś kompromisu. Ostatnio w zeszłym roku była przygotowana „,deklaracja śląska”, dokument który mieliśmy podpisać opracowany przez świętej pamięci Dietera Przedźwinga i w ostatnim momencie mniejszość niemiecka wyco- 
fała się z tego zamiaru i do tej pory nie podpisała tego dokumentu, mimo iż wydawało się, że jest to tylko formalność. Co gorsza, inicjatywa obywatelska, czyli 140 tys. podpisów, które zbieraliśmy, które trafiły do sejmu ma teraz pięć opinii przedłożonych do biura analiz sejmowych i tylko jedna jest negatywna podpisana jest przez przedstawiciela mniejszości niemieckiej. Nas to na Śląsku zabolało, mimo to widzę wolę współpracy wielu młodych przedstawicieli mniejszości niemieckiej. Wymaga to jednak pewnej równowagi politycznej. W tej chwili jest przekonanie władz mniejszości niemieckiej w województwie opolskim, że nie ma potrzeby dzielenia się władzą z dużo mniejszą organizacją. Lecz to jest kwestia czterech pięciu lat kiedy to się zmieni.

\section{Diethmar Brehmer}

Będę szanował państwa czas, bardzo popierał to stwierdzenie, że strach przed śląskością to jest strach przed nieznanym. To jest stały problem odkrywania Śląska. Jeśli chodzi o niemiecką spuściznę kulturową ona jest olbrzymia i w tej chwili odkrywamy perły. Nawet ja, który jestem co nieco wychowany w tej kulturze niemieckiej, odkrywam rzeczy, które są wspaniałe i to może być dar dla całej Polski. Co zrobimy jeśli to wszystko się stanie, muszę stwierdzić, że nasza opcja w województwie śląskim jest nakierowana na Ruch Autonomii Śląska. Dążąc do współpracy z Ruchem Autonomii Śląska pokazujemy swoją niezależność, pokazujemy, że jesteśmy rozczarowani zarówno stroną niemieckąjak i niestety stroną polską, dlatego idziemy swoim własnym traktem i będziemy wspierać ten ruch autonomii. Jednak od razu zaznaczam panie przewodniczący, że nasza współpraca będzie dotyczyła przede wszystkim budowania społeczeństwa obywatelskiego na Górnym Śląsku. Tutaj wszystko co się w tym pojęciu mieści, kapitał społeczny, to nas interesuje przede wszystkim. Szpica Ruchu Autonomii Śląska jest zorientowana bardzo politycznie, natomiast powinna się jeszcze rozbudować społecznie.

\section{Piotr Spyra}

Panie przewodniczący ile mam czasu bo mam sporo pytań? Zacznę od dwóch dotyczących mojego sformułowania o mnożenie bytów ponad konieczność. Nie mnie się wypowiadać w temacie zaniku języków, to państwo jesteście ekspertami, dla mnie problemem jest to, że śledząc dyskusje językoznawcze, etnologiczne dostrzegam coś co nazywam rewizjonizmem, kiedyś w badaniach tych panował pewien ład, formułowane tezy miały uzasadnienie naukowe i nagle w trakcie dość krótkiego czasu większość kwestii została w jakiś sposób zmieniona diametralnie. Natomiast mówię to w takim kontekście, że należy w tej dyskusji wyróżnić trzy pojęcia, postawić trzy pytania, czym jest język, czym jest dialekt, czym są gwary, na czym polega różnica między tymi pojęciami. Dla mnie nie ma żadnych przesłanek żeby uznać gwary śląskie za odrębny język, jest to grupa gwar, która spełnia wszystkie jakby znamiona dialektu, zgadzam się z tym, że jest to proces ruchomy, że jest to kwestia, która jest dynamiczna. Moim zdaniem dyskusyjne jest to, jaka jest rola nauki a jaka jest rola polityki, czy też działaczy społecznych? Czy nauka ma stawać się ideologią i wspierać pewne procesy polityczne, czy też nauka ma być nauką, która opisuje te procesy. W tym kontekście swoją tezę o rewizjonizmie językowym sformułowałem. Można bowiem powiedzieć, że dialekt podhalański, czy też gwary podhalańskie są jedynym dialektem, który mógłby spełniać kryteria pozwalające uznać go za język.

Glos z sali: Studenci nie powinni tego słuchać.

\section{Prowadzący, dr Cezary Trosiak}

Proszę pozwolić wypowiedzieć się panu wojewodzie.

\section{Piotr Spyra}

Bardzo dziękuję panie prowadzący. Sądziłem, że różnica zdań jest czymś naturalnym na uniwersytecie. Mam nadzieję, że się nie myliłem. Pani profesor pytała o mój język macierzysty. Moim języ- 
kiem macierzystym jest język polski, w moim domu - jako że jestem z pierwszego pokolenia z rodziny inteligenckiej o chłopskich korzeniach - mówiło się po polsku. Natomiast w całej pozostałej rodzinie się godało po śląsku, przy czym nigdy w mojej rodzinie nie rozróżniało się tego, wszyscy wiedzieli, że godają i byli z tego dumni nikt nie uważał, że jest kimś gorszym, że bawiąc się na podwórka i goda po śląsku to jest kimś gorszym. Wszyscy potrafili rozróżnić, że w oficjalnym obiegu mówi się po polsku, w kręgach prywatnych mówi się po śląsku. Nie byłem wychowany w sprzeczności wręcz w dumie $z$ gwary śląskiej, w takim przekonaniu, że gwara jest naszym kodem językowym, jest częścią języka polskiego. Nie było w tym żadnej sprzeczności, tak samo jak w tym, że w kościele mówiło się po polsku, że w szkole byłem uczony języka polskiego. Od swoich przodków dowiedziałem się, że walczyli oni o język polski w szkołach i kościele, że walczyli z germanizacją. W XIX wieku kiedy odrodziła się śląska tożsamość, ona się rozpoczęła od walki o język polski w szkole, walki o język polski w kościele. Ja jestem z tej tradycji. Kolejna kwestia, stwierdzenie, że zbyt daleko idące wnioski wyciagnąłem z moich rodzinnych doświadczeń, to jednak w tym miejscu przypomnę, że złożyłem zastrzeżenie, że jest to moje prywatne zdanie, które opiera się na moich doświadczeniach. Nie odmawiam innym prawa do innych doświadczeń, do innej drogi życiowej, zaznaczyłem tylko ten fakt, że staram się kierować moim poczuciem tożsamości, które realnie wynika $z$ takiego zakorzenienia jakie mam. W mojej rodzinie byli powstańczy śląscy. Inna sprawa, że obecnie powstania często błędnie nazywane są wojną domową. Często ci sami powstańcy, co było ich tragedią, musieli walczyć w Wehrmachcie i bardzo często kończyli wówczas wojnę w armii Andersa czy innych polskich formacjach. I jedno ostatnie pytanie, o to dlaczego w drugim spisie pozwolono wskazywać narodowość śląską? Z prostej przyczyny, bo tak zwane nieuznawanie, czyli nieprzyznanie statusu prawnego nie ma nic wspólnego z tym, że każdy ma prawo wyznawać dowolną tożsamość, jaką chce. Żadne demokratyczne państwo, członek Unii Europejskiej nie ma prawa żadnemu swojemu obywatelowi zabraniać deklarowania jego tożsamości. Polska łamałaby standardy, które sama sobie narzuciła, z których jesteśmy dumni, gdyby zamknęła listę narodowości dla swoich obywateli, listę, z której będą oni wybierać swoją tożsamość. W tym sensie problem jest, bo to jest problem sprzeczności tych deklaracji śląskich ze stanem prawnym. W tym stanie prawnym nie da się ich rozwiązać, dlatego należy się zastanowić na przyszłość co dalej z tym zrobić. Moja odpowiedź już padła, pójdźmy w stronę Francji, uznajmy, że narodowość, tożsamość etniczna jest kwestią prywatną, wszyscy jesteśmy członkami narodu obywatelskiego, a nie tak jak pan doktor sugerował, że podskórnie jest to naród etniczny. Idźmy w tę stronę i wszelkie problemy się rozwiążą.

\section{Jerzy Gorzelik}

Tak a propos tych spisów powszechnych, to mamy sytuację analogicznąjak w cesarstwie niemieckim, na które pan wojewoda tak często się obrusza, otóż wtedy też można było deklarować narodowość polską w spisie, ale też niewiele w tego wynikało. No może nie do końca, gdyż w pruskiej, a później niemieckiej szkole, nawet w dobie Kulturkampfu nie wyeliminowano języka polskiego. Teraz krótko postaram się odpowiedzieć na pytania. Pierwsze, tak naprawdę pytanie o program, co po uznaniu śląskiej mniejszości etnicznej na gruncie obowiązującej w Polsce ustawy. Otóż w zasadzie ze zdefiniowania problemu w moich poprzednich wypowiedziach wynika nasz program działania. Dzień po udaję się do rektora Uniwersytetu Śląskiego z wnioskiem o zmianę nazwy otwieranego kierunku silesianistyka w studium wiedzy o regionie, które ma wychowywać, kształcić kompetentnych nauczycieli edukacji regionalnej i do paru znanych mi profesorów, których nazwisk tu nie zdradzę, z prośbą o włączenie się do przygotowania programów nauczania i podręczników po to by zaradzić deficytowi pozytywnego kodu kulturowego w szkole na Górnym Śląsku. To było pewne uproszczenie, nie wiem czy zrobię to ja, czy Pejter Długosz, być może on jako reprezentant stowarzyszenia, dla którego kwestia uznania śląskiej mniejszości etnicznej jest tym absolutnym priorytetem. Dlatego on jest tu bardziej predystynowany do podjęcia tych działań. Ja natomiast będę działał na rzecz autonomii terytorialnej i przekształcenia Polski w państwo re- 
gionalne, o uzyskanie pewnej autonomii kulturowej, której Ślązakom ten wpis do ustawy jeszeze nie daje. Jednak nam jako społeczności regionalnej wpis ten pozwala na podjęcie działań modernizacyjnych, choćby poprzez wprowadzenie edukacji regionalnej ale podkreślam nowoczesnej edukacji regionalnej. To będzie możliwe kiedy ministerstwo edukacji, ministerstwo kultury będą w Poznaniu, Katowicach, Gdańsku, a nie będziemy mieli do czynienia z monopolem obecnego politycznego centrum, który wiąże się z absolutnym bezwładem, co odczuwamy w bardzo wielu dziedzinach życia. Dalej strach przed nieznanym to jest konstatacja, ale ona podsuwa pewną refleksję, której nie zawarłem w swojej wypowiedzi na temat skutków działań obecnej ustawy. Otóż tak naprawdę my myślimy tylko w jedną stronę, myślimy o tym, że mniejszości powinny mieć swobodę takiej autoekspresji, działalności edukacyjnej i kulturalnej, powinniśmy szukać rozwiązania żeby polska większość uczyła się o mniejszościach, czy uczyła się mniejszości. Tak jak Ignacy Baudouin de Courtenay w okresie dwudziestolecia międzywojennego głosił postulat wprowadzenia jidysz do polskiej szkoły, a do szkół mniejszościowych żydowskich języka polskiego. Pytanie o granice Górnego Śląska, to rzeczywiście warto zdefiniować, choć Zagłębie to na pewno nie Górny Śląsk. Muszę powiedzieć, że dla mnie ujmujące jest to, nawiązując do wypowiedzi pana doktora Wichierkiewicza, że społeczność wilamowska dostrzega w śląskości pewne oparcie. Bardzo bym chciał żeby ta górnośląskość, którą w jakimś stopniu konstruujemy, nie wahajmy się powiedzieć, że tożsamość jest pewnym performersem, chcielibyśmy aby była ona ostoją dla różnych takich mikrotożsamości, żeby to właśnie była ta otulina, w której te tożsamości mogą znaleźć swoje oparcie. Myślę że to by było urzeczywistnieniem pewnego ideału, jak chcemy budować. I tu można by od razu przejść do wypowiedzi pana profesora Sadowskiego, który mówi o pluralistycznym narodzie kulturowym. To jest dla Górnoślązaków tak naprawdę olbrzymie wyzwanie. Nie wiem czy temu wyzwaniu sprostają, ale mam nadzieję, że tak właśnie będzie. W duchu tego pluralizmu chciałem zaoponować, Waldku Zgorzelec to Górne Łużyce nie Śląsk. Śląsk kończy się na Kwisie, nie bądźmy imperialistami wobec naszych Górnołużyckich sąsiadów.

\section{Prowadzący, dr Cezary Trosiak}

Szanowni państwo przebieg debaty był wyczerpujący, uczestnicy są zmęczeni, niemal wszyscy studenci opuścili już salę. Jak można to zinterpretować? Możliwe są dwa warianty, zajęcia się skończyły, to wyszli, gdyż mają następne. Inna możliwość jest taka, że nie rozumieją o czym my tu rozmawiamy, skoro jest jakaś grupa, która inaczej definiuje swoją tożsamość, to należy to uszanować, a nie tworzyć sztucznego problemu. Proszę państwa obiecałem, że uczestnicy będą mogli sobie wzajemnie zdawać pytania, lecz czas na debatę i tak przekroczyliśmy o ponad 30 minut. Proponuję abyśmy tę dyskusję przenieśli do kuluarów oraz do panelu śląskiego, który jest kolejnym punktem naszej konferencji i zaczyna się zaraz po przerwie kawowej.

\section{Jerzy Gorzelik}

Ślązaków znowu oszukali i to tym razem Wielkopolanie.

\section{Prowadzący, dr Cezary Trosiak}

Szanowni Państwo Wielkopolanie zawsze wspierali Górnoślązaków, by wskazać tu postać Wojciecha Korfantego i zapewniam, że tak jest nadal. Chciałbym podziękować wszystkim uczestnikom naszej dyskusji, za to że zechcieli pokonać odległość 300 kilometrów, aby kontynuować dyskusję, którą toczą ze sobą tam na Górnym Śląsku i przybliżyć nam jej główne wątki. Cała dyskusja została zarejestrowana i zostanie zamieszczona w jednym z najbliższych numerów „Przeglądu Politologicznego". 
